\title{
Select primary source bibliography
}

\author{
Manuscript sources
}

All Souls College, Oxford

Charles Richard Vaughan Papers, Reels 3, 5-11, 16, 18, 22, 23, 24, 27, 28, 30 .

\section{Balliol College, Oxford}

Morier MS Class A, Boxes 1-2. Isaac Morier Papers; Class C, Boxes 1-2. John Philip Morier Papers Class D, Boxes 1-2. James Justinian Morier Papers; Class E, Boxes 1-9 and Class F, Boxes 1-2. David Richard Morier Papers; Class G, Boxes 1-4, Box 8. Anna Burnet Morier Papers.

\section{British Library}

BL Add MS 19309-15, 23729-30, 60537 and Egerton 1969, 2001-2. John Strange Papers; Add MS 4319. Letters to Thomas Birch; Add MS 33349. Letters to Thomas Martyn, Add MS 36593. Letters to Caleb Whitefoord Add MS 22358, Add MS 51389, 62665. George Macartney Papers

Add MS 34048, 40714-16, 41198, 42069, 42071, 51315, 60391A and Egerton 2641. William Hamilton Papers

Add MS 34412-34426. Auckland Papers

Add MS 35354-72, 35385, 35433. Joseph Yorke Papers

Add MS 35461-35495. Robert Keith Papers

Add MS 42774A. George Rose Papers

Add MS 46825. Francis Drake Papers

Add MS 47565, 47594. Fox Papers

Add MS 48291, 48383-48396, 48398-48416. Paget Papers

Add MS 51389. Holland House Papers

Add MS 57305-7. Edward Weston Papers

Egerton 1615-1619. Emma Hamilton Papers. Correspondence with Queen Maria Carolina of Naples

Egerton 2157. James Porter Papers; Add MS 32418-22, Letters to Caspar Wetstein

Egerton 3404. Newcastle Papers

Egerton 3414-15, 3455, 3463. Holdernesse Papers 


\section{Bodleian Library}

Dep Bland Burges, 30, 31, 33-6, 38, 45, 47-8, 51, 58, 62. James Bland Burges Papers

Shelburne MS 35-8, 48-9, 58, 63, 74. Bowood Muniments, Papers of William Petty, 2nd Earl of Shelburne

Bod MS Eng misc. e. 105. William Hamilton Notebooks

Bod MS Eng misc. c. 488. Mediterranean Travel Diary of Henry Watkin Williams Wynn, 1811-12

Bod MS Eng hist. c. 62. John Goodricke Papers

Bod MS Eng. hist b. 238 and Eng. hist c. 1032. Francis Peter Werry Papers.

Bod MS Eng hist. c. 4861-2. Westmoreland Papers (Burghersh)

Bod MS Eng hist. g. 15. William Hamilton Papers

Bod MS Eng. lett. b. 23. George Macartney Papers. Correspondence. Bod MS Eng. lett. d. 374, Bod MS Eng misc. f. 534 (notebook) Bod MS Eng misc. b. 162 (notebook)

Bod MS Eng, lett. c. 336-40. Rochford Papers

Bod MS Eng lett. c. 392. Charles Stuart de Rothsay's Travel Journal through Northern Europe, 1801

Bod MS Eng lett d. 76. George Cressener Papers

\section{Burnet of Kemnay Papers, Kemnay House, Aberdeen}

Bundles 22, 24, 25, 31, 36, 39, 55-58, 61, 64-6, 74, 76-78, 82-89, 71.

\section{Durham Record Office, County Hall, Durham}

Londonderry Estate Papers, D/Lo/C3, 7, 9, 16, 18-19, 20-1, 23-24, 28, 38, 44-8, 55-9, 63, 100, 118, 120, 123, 125, 482, 493.

59/29. Imprisonment in France

\section{Elgin MS, Broomhall, Fife}

60/1. Diplomatic Correspondence and Intelligence Reports. Brussels, Vienna,

Berlin

60/2. Berlin, Official \& Private Correspondence

60/3. Family and Personal Correspondence

60/4. Marbles and Other Collections

60/11. Intelligence Reports from Turkey

60/16. Relations with the Porte

60/17. Official Correspondence - Turkey

60/22. General Administration - Turkey

Sir Harry Wilson, 'Eight chapters of the life of Lord Elgin', unpublished MS (1921).

Library of Congress, Washington, DC

Augustus John Foster Papers, vols 1-10 and 14 
Lewis Walpole Library, Yale University

Charles Hanbury Williams Papers, vols 8, 10, 11, 12, 14, 18, 21, 28, 30, 34, 35, $37,39,51-4,56-8,60-1,63-4,67,71-3,75-6$.

Edward Weston Papers W53, Reels 2-7, Vols 3, 5-6, 11-14, 21.

\section{Mansfield Papers, Scone Castle, Perth}

Papers of David Murray, 2nd Earl of Mansfield.

TD 2002/13, Boxes 58-60, 110, 113, 115-16.

TD 2002/13, Bundles 650-1, 681, 701.

TD 2002/42, Boxes 3, 13-20, 22.

TD 2002/42, 2nd Series, Bundles 578, 584, 585, 624, 625, 626, 628, 629, 632, 634, 637, 638 .

\section{Merton College, Oxford}

Malmesbury Papers F.3.3(1) - 3.3(3). Family and Personal Correspondence

\section{National Archives, Kew}

FO 5/1-260. United States of America

SP 78/234-308, FO 27/1-412. France

SP 91/50-111, FO 65/1-185. Russia

PRO 30/29/17/1. Harriet Granville Papers

PRO 30/43/30/1-2 and 31/1. Malmesbury Papers

\section{National Library of Scotland}

NLS MS Acc. 9769 72/1-3. Robert Murray Keith Papers

NLS MS Dep 313/742. Sutherland Papers

NLS 2968-9. Culloden Papers

NLS MS 5510-5721. Robert and Henrietta Liston Papers

NLS MS 6160-6246, 15386-15390, 21297, 21299. Charles Stuart de Rothsay Papers

NLS MS 11084, 12954, 12959, 12960, 12963, 12965, 12966, 12969, 12979, 12980, 12982, 12983, 12984, 12963, 12966, 12969, 13018, 13019. Hugh Elliot Papers

NLS MS 11084, 11104, 11105, 11106, 11108, 11130, 11792, 11196, 11249 , 11267. Gilbert Elliot Papers

NLS 11111-11119. Anna Maria Elliot Papers

\section{National Library of Wales}

NLW MS 2787-97D, 2802-03D, 4816D. Henry Williams Wynn Papers

\section{Public Record Office of Northern Ireland}

PRONI D.572/17, D.2225/2 and 5. George Macartney Papers

PRONI D.2433/D/1. Robert Murray Keith Papers

PRONI D.3618/A-C. Augustus John Foster Papers 
PRONI D.3030/D, F, G, Q2, P2-4, 7-8, T2. Castlereagh Papers, Family Correspondence

PRONI D.3030/3392-5639. Castlereagh Papers, Political and Diplomatic Correspondence

PRONI D.3044/D-F. Clanwilliam Papers

\section{Printed primary sources}

Material already cited in the abbreviations has not been listed here.

Adair, R., Historical Memoir of a Mission to the Court of Vienna in 1806, by The Rt. Hon. Sir Robert Adair, G.C.B. With a Selection of His Dispatches, Published by Permission of the Proper Authorities (London: Longman, 1844).

- The Negotiations for the Peace of the Dardanelles in 1808-9: With Dispatches and Official Documents, by the Right Honourable Sir Robert Adair, G.C.B., being a Sequel to the Memoir of his Mission to Vienna in 1806, 2 vols (London: Longman, 1845).

Barrow, J. (ed.), Some Account of the Public Life, and a Selection of the Unpublished Writings, of the Earl of Macartney, 2 vols (London: T. Cadell \& W. Davies, 1807).

Bissett, A. (ed.), Memoirs and Papers of Sir Andrew Mitchell, 2 vols (London: Chapman and Hall, 1850).

Bonnard, G.A. (ed.), Gibbon's Journey from Geneva to Rome: His Journal from 20 April to 2 October 1764 (London: Thomas Nelson and Sons, 1961).

Broadley, A.M. (ed.), The Journal of a British Chaplain in Paris during the Peace Negotiations of 1801-2, From the Unpublished MS of the Revd. Dawson Warren, M.A., unofficially attached to the Diplomatic Mission of Mr. Francis James Jackson (London: Chapman, 1913).

Browning, O. (ed.), Despatches from Paris, 1784-1790, 2 vols (Cambridge: Cambridge University Press, 1910).

- The Despatches of Lord Gower, English Ambassador at Paris from June 1790 to August 1792, to Which Are Added the Despatches of Mr. Lindsay and Mr. Monro, and the Diary of Viscount Palmerston (Cambridge: Cambridge University Press, 1885).

Burghersh, [John], Memoir of the Early Campaigns of the Duke of Wellington in Portugal and Spain, By an Officer Employed in His Army (London: John Murrray, 1820).

- Memoir of the Operations of the Allied Armies, under Prince Schwartzenberg, and Marshal Blucher, During the Latter End of 1813, and the Year 1814 (London: John Murray, 1822).

Burnet-Milton, S., Without Fanfare: The Story of My Family (Aberdeen: Kemnay House Press, 1994).

Canning, S., Why I Am a Christian (London: H.S. King and Co., 1873)

- The Greatest of Miracles (London: Hatchards, 1876).

Chad, George William. A Narrative of the Late Revolution in Holland (London: John Murray, 1814). 
Collyer, A. (ed.), Despatches and Correspondence of John, Second Earl of Buckinghamshireshire, Ambassador to the Court of Catherine II of Russia 1762-1765, 2 vols (London: Longman, 1900).

Dutens, L., Memoirs of a Traveller, Now in Retirement. Written by Himself. Interspersed with Historical, Literary, and Political Anecdotes, Relative to Many of the Principal Personages of the Present Age. Translated from the French, under the Superintendance of the Author (London: Phillips, 1806).

Gillespie-Smyth, A. (ed.), The Romance of Diplomacy: Historical Memoir of Queen Carolina Matilda of Denmark, Sister to King George the Third. With Memoir, and a Selection from the Correspondence (Official and Familiar) of Sir Robert Murray Keith, K.B., Envoy Extraordinary and Minister Plenipotentiary at the Courts of Dresden, Copenhagen and Vienna, 2 vols (London: James Hogg \& Sons., 1861).

Grieg, J.Y.T., The Letters of David Hume, 2 vols (Oxford: Clarendon Press, 1932).

Gronow, R.H., The Reminiscences and Recollections of Captain Gronow, being Anecdotes of the Camp, Court, Clubs, and Society 1810-1860, 2 vols (London: J.C. Nimmo, 1892).

Hare, A.J.C., The Story of Two Noble Lives, being Memorials of Charlotte, Countess Canning, and Louisa, Marchioness of Waterford, 3 vols (G. Allen, 1893).

Harris, J. (ed.), Letters of the First Earl of Malmesbury, to His Family and Friends, from 1745 to 1820, 2 vols (London: R. Bentley, 1870).

Hamilton, W., Campi Phlegraei. Observations on the Volcanoes of the Two Sicilies, 2 vols (Naples: privately printed, 1776).

Hassan, M.A., A Persian at the Court of King George 1809-10: The Journal of Mirza Abul Hassan Khan, trans. M.M. Cloake (London: Barrie \& Jenkins, 1988).

Hylton, Lord (ed.), The Paget Brothers, 1790-1840 (London: John Murray, 1918).

Ilchester, Earl of (ed.), The Journal of Elizabeth Lady Holland (1791-1811) 2 vols (London: Longman, 1908).

Lane-Poole, Stanley, The Life of the Right Honourable Stratford Canning, Viscount Stratford de Redcliffe, from his Memoirs and Private and Official Papers, 2 vols (London: Longmans, Green, 1888).

Larpent, G., Turkey: Its History and Progress, from the Journals and Correspondence of Sir James Porter, 2 vols (London: Hurst and Blackett, 1854).

Leveson-Gower, G. and Irish Palmer (eds), Hary-O: The Letters of Lady Harriet Cavendish 1796-1809 (London: John Murray, 1940).

Lodge, R., Private Correspondence of Sir Benjamin Keene (Cambridge: Cambridge University Press, 1933).

Londonderry, [Charles]. Narrative of the Peninsular War: From 1808 to 1813 (London: Henry Colburn, 1828).

- Narrative of the War in Germany and France, in 1813 and 1814, 2nd edn (London: Henry Colburn and Richard Bentley, 1830). 
- Recollections of a Tour in the North of Europe, in 1836-1837, 2 vols (London: Richard Bentley, 1837).

- Correspondence, Despatches, and other Papers of Viscount Castlereagh, 2nd series, 4 vols (London: H. Colburn, 1848-51).

Mallet, J.L., An Autobiographical Retrospective of the First Twenty-five Years of His Life, Printed for Private Circulation (Windsor: Thomas E. Luff, 1890).

Martens, J.G., Precis du droit des gens modernes de l'Europe, fondé sur les traités et l'usage. Auquel on a joint la liste des principaux traités conclus depuis 1748 jusqu'à présent, avec l'indication des ouvrages où ils se trouvent, 2 vols (Gottingen: J.C. Dieterich, 1789).

More, H., Strictures on the Modern System of Female Education, 3rd edn, 2 vols (London: T. Cadell and W. Davies, 1799).

Morier, D.R., What Has Religion to Do with Politics? The Question Considered, in Letters to His Son (London: John W. Parker, 1848).

- Photo the Suliote: A Tale of Modern Greece, 3 vols (London: L. Booth, 1857). Morier, J.J., A Journey through Persia, Armenia and Asia Minor to Constantinople, in the Years 1808 and 1809 (London: Longman, 1812).

- A Second Journey through Persia, Armenia and Asia Minor, to Constantinople, Between the Years 1810 and 1816. With a journal of the voyage by the Brazils and Bombay to the Persian Gulf. Together with an account of the proceedings of His Majesty's embassy under . . . Sir Gore Ouseley (London: Longman, 1818).

- The Adventures of Hajii Baba of Ispahan (London: J. Murray, 1824).

- The Adventures of Hajii Baba of Ispahan in England (London: J. Murray, 1828).

Nisbet Hamilton Grant, J.P., The Letters of Mary Nisbet of Direlton, Countess of Elgin (London: John Murray, 1926).

Nugent, T., The Grand tour, or, A journey through the Netherlands, Germany, Italy, and France . . . 2nd edn, 4 vols (London: D. Browne, A. Millar, G. Hawkins, W. Johnston, P. Davey and B. Law, 1756).

Pottle, F.A. (ed.), Boswell on the Grand Tour: Germany and Switzerland (New York: McGraw Hill, 1953).

Robinson, L.G. (ed.), Letters of Dorothea, Princess Lieven, during Her Residence in London, 1812-1834 (London: Longman, 1902).

Rose, G.H., Scriptural Researches (London: J. Hatchard and Son, 1832)

Ross, C. (ed.), The Correspondence of Charles, First Marquis Cornwallis, 3 vols (London: J. Murray, 1859).

Smith, W.J. (ed.), The Grenville Papers: Being the Correspondence of Richard Grenville Earl Temple, K.G. and The Right Hon. George Grenville, Their Friends and Contemporaries, 4 vols (London: J. Murray, 1852).

Staël, G. de, Ten Years of Exile, trans. A.H. Goldberger (De Kalb: Northern Illinois University Press, 2000).

Staunton, G., An Authentic Account of An Embassy from the King of Great Britain to the Emperor of China; Cursory Observations Made, and Information Obtained, in Travelling through That Ancient Empire, and a 
Small Part of Chinese Tartary. Together with a Relation of the Voyage undertaken on the Occasion, by HM Ship the Lion, and the Ship Hindostan, in the East India Company's Service, to the Yellow Sea, and Gulf of Pekin; as Well as of Their Return to Europe, 2 vols (London: G. Nicol, 1797).

Taylor, W.S. and J. Pringle (eds), Correspondence of William Pitt, Earl of Chatham, 4 vols (London: J. Murray, 1838-40).

Weigall, R. (ed.), The Correspondence of Lord Burghersh, afterward Eleventh Earl of Westmorland 1808-1840 (London: John Murray, 1912).

- The Letters of Lady Burghersh. afterwards Countess of Westmorland from Germany and France during the Campaign of 1813-14 (London: John Murray, 1893).

Wellington, [A.R.] (ed.), Despatches, Correspondence and Memoranda of Field Marshal Arthur, Duke of Wellington, 8 vols (London: J. Murray, 1867).

Wharncliffe, Lord (ed.), The Letters and Works of Lady Mary WortleyMontagu, 2 vols (New York: AMS Press, 1970).

Wickham, W. (ed.), The Correspondence of the Right Honourable William Wickham, from the Year 1794 [to 1799], 2 vols (London: Bentley, 1870).

Worsley, R., A Catalogue Raisonné of the Principal Paintings, Sculptures, Drawings, \&c. \&c. at Appledurcombe House, the Seat of the Rt. Hon. Sir Richard Worsley, Bart. (London: William Bulmer and Co., 1804).

- Museum Worsleyanum or a Collection of Antique Basso Relievos, Bustos, Statues, and Gems with views of Places in the Levant taken on the spot in the years 1785-6 and 7, 2 vols (privately printed, 1782).

Wortley Montagu, M., Letters of the Right Honourable Lady M[ar]y W[ortle] y M[ontagu]e: Written, during Her Travels in Europe, Asia and Africa, to Persons of Distinction, Men of Letters, Gc. in Different Parts of Europe. Which Contain, Among Other Curious Relations, Accounts of the Policy and Manners of the Turks; Drawn from Sources That Have Been Inaccessible to Other Travellers, 3 vols (London: Becket \& P.A. De Hondt, 1763). 